\title{
DISCLAIMER
}

This report was prepared as an account of work sponsored by in agency of the United States Government. Neither the United States Government nor any agency thereof, nor any of their employees, makes any warranty, express or implied, or assumes any legal liability or responsibility for the accuracy, completeness, or usefulness of any information, apparatus, product, or process disclosed, or represents that its use would not infringe privately owned rights. Reference herein to any specific commercial product, process, or service by trade name, trademark, manufacturer, or otherwise does not necessarily constitute or imply its endorsement, recommendation, or favoring by the United States Government or any agency thereof. The views and opinions of authors expressed herein do not necessarily state or reflect those of the United States Government or any agency thereof.

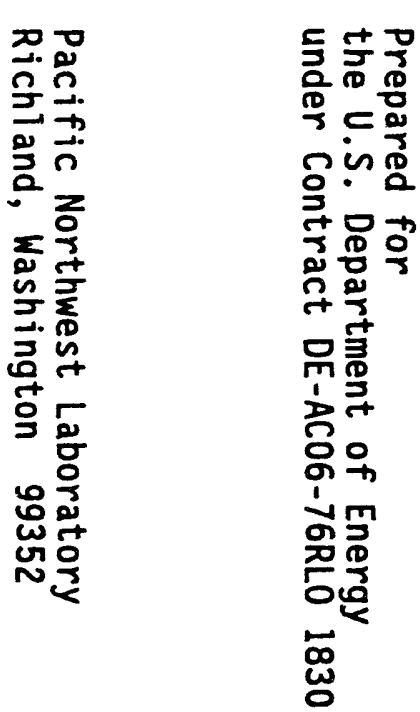

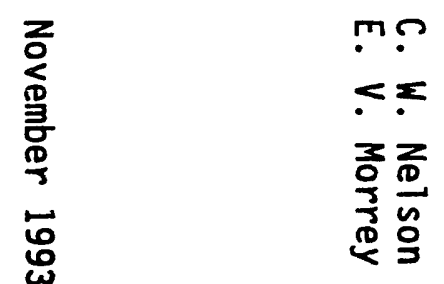




\section{Radioactive Waste Vitrification \\ Offgas Analysis Proposal}

\section{Summary}

Further validation of the Hanford Waste Vitrification Plant (HWVP) feed simulants will be performed by analyzing offgases during crucible melting of actual waste glasses and simulants. The existing method of vitrifying radioactive laboratory-scale samples will be modified to allow offgas analysis during preparation of glass for product testing. The analysis equipment will include two gas chromatographs (GC) with thermal conductivity detectors (TCD) and one $\mathrm{NO} / \mathrm{NO}_{x}$ analyzer. This equipment is part of the radioactive formating offgas system. The system will provide real-time analysis of $\mathrm{H}_{2}, \mathrm{O}_{2}, \mathrm{~N}_{2}, \mathrm{NO}$, $\mathrm{N}_{2} \mathrm{O}, \mathrm{NO}_{2}, \mathrm{CO}, \mathrm{CO}_{2}, \mathrm{H}_{2} \mathrm{O}$, and $\mathrm{SO}_{2}$. As with the prior melting method, the product glass will be compatible with durability testing, i.e., Product Consistency Test (PCT) and Material Characterization Center (MCC-1), and crystallinity analysis. Procedures have been included to ensure glass homogeneity and quenching. The radioactive glass will be adaptable to $\mathrm{Fe}^{+2} / \Sigma \mathrm{Fe}$ measurement procedures because the atmosphere above the melt can be controlled. The $325 \mathrm{~A}$-hot cell facility is being established as the permanent location for radioactive offgas analysis during formating, and can be easily adapted to crucible melt tests. The total costs necessary to set up and perform offgas measurements on the first radioactive core sample is estimated at $\$ 115 \mathrm{~K}$. Costs for repeating the test on each additional core sample are estimated to be $\$ 60 \mathrm{~K}$. The schedule allows for performing the test on the next available core sample.

\section{Justification}

The source of most design/design verification data for HWVP is from laboratory, bench, and pilot-scale tests using simulated waste feeds. A critical complement to these data are corresponding radioactive data, which provides a comparison between the simulant and actual feeds. The simulant preparation methods developed by HWVP must produce simulants representative of the actual waste or they are invalid for plant design. 
For example, do the precipitation, decanting, and washing steps that we use to produce simulant neutralized current acid waste (NCAW) result in a feed that melts similarly to the real NCAW? The proposed work is designed to answer this question by confirming that simulants are representative of the actual waste relative to melting offgas behavior. The testing will provide a direct comparison of offgas behavior during calcination and vitrification. The testing will provide data on offgas generation rates and speciation for designing and sizing plant equipment (i.e., $\mathrm{NO}_{\mathrm{x}}$ scrubber design and pipeline sizing), permitting, and safety.

The core sample offgas data are needed to assess safety issues related to hydrogen and ammonia evolution. Initial tests performed on crucible melts of formic acid treated NCAW showed considerable hydrogen generation. Although the hydrogen will normally combust in a melter system having plenum heaters, the hydrogen data are important to ensure safe design under all operating conditions. Ammonia in the presence of $\mathrm{NO}_{\mathrm{x}}$ can form potentially explosive levels of ammonium nitrate in the ventilation system. The presence of organics can also act as a sensitizer for the detonation. The offgas data collected from core samples will provide information relative to these hazards.

Performing offgas analyses on the radioactive core samples provides the capability to assess the effects of actual waste composition variation on melter offgas generation. In the bench-scale radioactive melter, only a very limited number of runs with the major waste types will be performed to assess and compare offgas compositions.

Each of the HWVP waste types will produce different types and amounts of melter offgases and possible hazards. Analysis of each core sample is important to characterize offgas behavior of the different waste types during calcination and vitrification. Core samples are expensive and rare, and proper data collection is essential for each sample. If this offgas data is not collected while processing a sample, the data are lost. Delaying data collection to out-year core samples could cause permitting, safety, and economic problems because of major plant modifications. 
The proposed offgas testing will provide a valid radioactive data base for permitting applications. The radioactive data will provide credible source terms as well as validate nonradioactive source terms. Certain volatiles of interest to Washington State and the Environmental Protection Agency may only be measurable on radioactive samples.

Because of the complex nature of HWVP feeds, the chemical reactions that occur during the transformation of feed into glass have only been hypothesized. Many variables govern the reaction paths: the temperature ramp rate, the oxidation state of the feed, and the atmosphere above the cold cap, etc. P. Hrma and D-S. Kim (PNL) are conducting online offgas analyses during the calcination and vitrification of simulated HWVP feeds. Their work, along with complementary radioactive testing, will lead to an increased understanding of the cold cap chemistry and justification for retaining or modifying the current hypotheses.

\section{Background}

In recent work, J. L. Ryan (PNL) has hypothesized several reactions governing the melting of formated waste. The basis assurnptions and hypothesized reactions are as follows:

Assumptions of Waste Composition:

- Slurry is depleted of hydroxides, nitrites, and carbonate.

- Slurry contains nitrates, formates, and nitrates of metal salts.

Hypothesized Cold Cap Chemistry:

- When gases come off at low temperatures (i.e., $300^{\circ}$ to $500^{\circ} \mathrm{C}$ ), they can escape easily through the porous cold cap.

- When gases come off at high temperatures (i.e., $700^{\circ}$ to $900^{\circ} \mathrm{C}$ ), they cannot escape well through the viscous glass, causing foaming.

- Evidence shows that acid waste (e.g., formated waste) produces less foaming.

- As gases escape the glass, it carries $\mathrm{H}_{2} \mathrm{O}$ with it. 
Hypothesized reactions are shown in Table 1.

Table 1. Cold Cap Reactions of Formated Waste

\begin{tabular}{|c|c|c|}
\hline Temperature & Sample Progress & Reaction \\
\hline $100^{\circ}-200^{\circ} \mathrm{C}$ & Sample drys & Free $\mathrm{H}_{2} \mathrm{O}$ is lost. \\
\hline $200^{\circ}-300^{\circ} \mathrm{C}$ & $\mathrm{NaCOOH}$ ' and $\mathrm{NaNO}_{3}$ form eutectics. & $\begin{array}{l}\mathrm{NaCOOH} \text { melting point }=253^{\circ} \mathrm{C} \\
\mathrm{NaNO} \text {, melting point }=300^{\circ} \mathrm{C}\end{array}$ \\
\hline $325^{\circ} \mathrm{C}$ & $\begin{array}{l}\text { Nitrate and formate reactions } \\
\text { complete in }<1 \mathrm{~h} \text {. }\end{array}$ & $\begin{array}{l}\mathrm{NaCOOH}+\mathrm{NaNO}_{3}-> \\
1 / 2 \mathrm{Na}_{2} \mathrm{CO}+\mathrm{NaNO}_{2}+1 / 2 \mathrm{CO}_{2} \uparrow+1 / 2 \mathrm{H}_{2} \mathrm{O} \uparrow \\
\mathrm{NaCOOH}^{-\mathrm{NaNO}_{2}} \rightarrow> \\
\quad \mathrm{Na}_{2} \mathrm{CO}+1 / 2 \mathrm{~N}_{2} \mathrm{O} \uparrow+1 / 2 \mathrm{H}_{2} \mathrm{O} \uparrow\end{array}$ \\
\hline$\sim 400^{\circ} \mathrm{C}$ & $\begin{array}{l}\text { All nitrate, nitrite, and liquid are } \\
\text { gone. }\end{array}$ & $\begin{array}{l}2 \mathrm{NaHCO}->\mathrm{Na}_{2} \mathrm{CO}_{3}+\mathrm{CO} \uparrow+\mathrm{H}_{2} \uparrow \\
2 \mathrm{NlaCOOH} \text { be consisent on formulas }\end{array}$ \\
\hline $580^{\circ}-700^{\circ} \mathrm{C}$ & $\begin{array}{l}\text { Some nitrate may still be present (if } \\
\text { not enough reductant is added or it } \\
\text { did not work effectively), which will } \\
\text { react as batch becomes liquid. } \\
\text { Further metal reductions }\end{array}$ & $\mathrm{Na}_{2} \mathrm{MnO}_{4}+\mathrm{SiO}_{2} \rightarrow \mathrm{MAO}_{1}+2$ \\
\hline $700^{\circ}-900^{\circ} \mathrm{C}$ & $\begin{array}{l}\text { Sodium carbonate destruction } \\
\text { High oxidation state metals reduce } \\
\text { (e.g. } \mathrm{Mn}^{+6} \text { to } \mathrm{Mn}^{+4} \text { as } \mathrm{SiO}_{2} \text { goes.into-- } \\
\text { solution and } \mathrm{Na}_{2} \mathrm{CO}_{3} \text { decomposes). }\end{array}$ & $\begin{array}{l}\mathrm{Na}_{2} \mathrm{CO}_{3}+\mathrm{SiO}_{2} \rightarrow> \\
\mathrm{Na}_{2} \mathrm{SiO}_{3}+\mathrm{CO}_{2} \uparrow \\
\text { reduction to } \mathrm{Mn}^{+2} \text { alveady } \\
\text { shom'n above } 580-700{ }^{\circ} \mathrm{C}\end{array}$ \\
\hline $700^{\circ}-1150^{\circ} \mathrm{C}$ & Further reduction of metals & $\begin{array}{l}\text { For almost all elements, the higher oxidation } \\
\text { states become less stable at higher } \\
\text { temperatures. Reactions generate } \mathrm{O}_{2} \text {. }\end{array}$ \\
\hline
\end{tabular}

The proposed offgas system will monitor for $\mathrm{H}_{2} \mathrm{O}, \mathrm{CO}_{2}, \mathrm{O}_{2}, \mathrm{~N}_{2} \mathrm{O}, \mathrm{H}_{2}, \mathrm{~N}_{2}, \mathrm{NO}, \mathrm{NO}_{2}$, $\mathrm{CO}$, and $\mathrm{SO}_{2}$, which will allow testing of these hypotheses. By comparing the stoichiometric ratios of the offgases, hypothesized reaction mechanisms can be tested.

Offgas equipment procured for analysis of radioactive core samples was used to support the first crucible melt tests performed by P. Smith and J. Vienna (PNL). During 
melting of simulant NCAW, significant quantities of several gases were detected and monitored (i.e., $\mathrm{H}_{2} \mathrm{O}, \mathrm{CO}_{2}, \mathrm{O}_{2}, \mathrm{~N}_{2} \mathrm{O}, \mathrm{H}_{2}, \mathrm{CO}$, and $\mathrm{NO}$ ). A preliminary look at the data indicate that additional reactions were occurring other than those stated above. Tests like these will be valuable in understanding cold cap chemistry and causes of foaming in the meiter, if they are valid with respect to scaleup. The equipment used, which is the same as that proposed for radioactive testing, was functional and reliable.

\section{Approach}

Gas collection and analysis from radioactive operations in shielded facilities is a standard procedure. Recent work in laboratory-scale, radioactive formating offgas analysis and nonradioactive crucible melt offgas analysis has provided valuable experience. As a result of the radioactive offgas analysis during both types of testing, it is evident that the proposed system will perform as expected and will accurately provide the necessary information. A conceptual design for an offgas analysis system to be employed in a hot cell facility is shown in Figure 1.

Gases generated during calcination and vitrification will be swept through the system using argon with a helium tracer or other gases as justified. The flow of carrier gas will be regulated using a mass-flow controller. After the carrier gas sweeps through the crucible and mixes with the offgases, it will be mixed with an additional carrier gas to bring the dew point to below $25^{\circ} \mathrm{C}$. The gases will then pass through a condenser equipped with a condensate trap. The condenser and trap are an added ensurance that condensable water does not damage the high-efficiency particulate air (HEPA) filters and analytical equipment. As the gases leave the hot cell, they will pass through a HEPA filter on each side of the cell wall. Offgases will then be sampled every $11 \frac{1}{2} \mathrm{~min}$ by the GCs, which separate the gases using two different columns (Mole Sieve and Pora Plot $U$ or $Q$ ). A small amount of offgas will be vented to the fume hood just following the GCs to allow gas analysis at atmospheric pressure. A metal bellows pump will then raise the line pressure between 5 and 10 pounds per square inch (psi), which is 


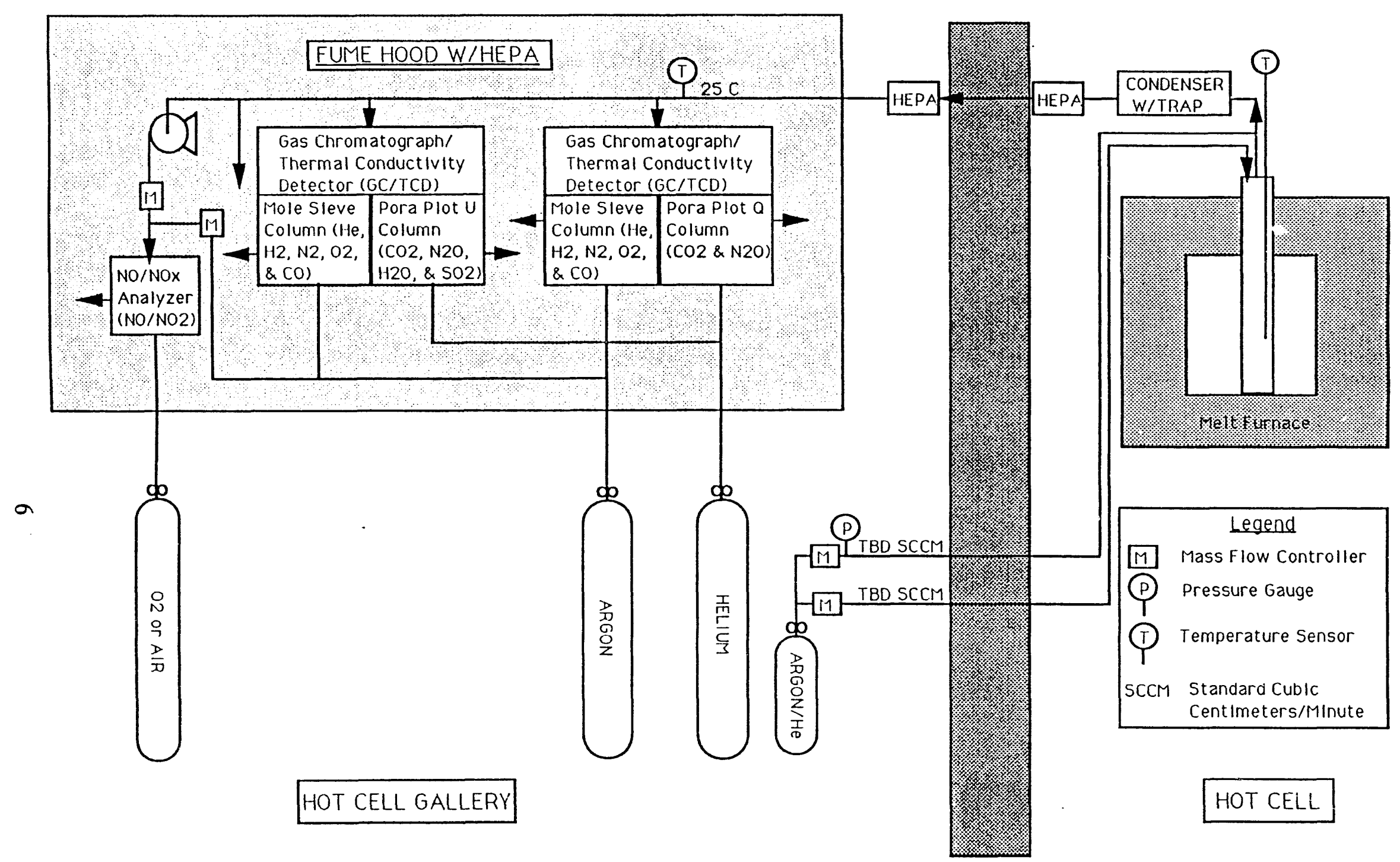

Figure 1. Proposed Crucible Melt Offgas System (Radioactive) 
required for the $\mathrm{NO} / \mathrm{NO}_{\mathrm{x}}$ analyzer. Following the metal bellows pump, a mass-flow controller supplies the $\mathrm{NO} / \mathrm{NO}_{\mathrm{x}}$ analyzer with a constant volume of offgas, which is blended with a constant volume of argon for dilution. All of the instruments and the remaining gas will be vented to the fume hood and building ventilation, both having HEPA filtration.

The melt furnace is a high-temperature tube furnace that can easily be adapted for remote operations (see Figure 2). The furnace is equipped with a programmable controller and will be capable of accurate temperature ramp rate during the melt process. An elongated alumina crucible will be used for the melt tests. Melting, quenching, annealing, and cooling will take place within the same crucible. When annealing and cooling are complete, the glass melt will be trimmed from the alumina crucible using a wafering saw. The square geometry is preferred to enable trimming the glass/crucible interface with minimal sample loss. Because there is no need to pour the glass, there will be less wasted glass and more available for testing.

\section{Required Equipment}

The following is a list of the equipment used in the system and a record of its availability:

Gas Chromatographs (2)

$\mathrm{NO} / \mathrm{NO}_{\mathrm{x}}$ Analyzer

Mass-flow Controllers (3)

Metal Billows Pump

Data Acquisition Software

Data Acquisition/Control

Computers (3)

Pressure and Temperature Gauges

High-Capacity Mass-flow Controller

Custom Alumina Crucibles

Melt Furnace

Annealing Furnace

Calibration/Carrier Gases

Wafering Saw
Currently Available

Currently Available

Currently Available

Currently Available

Currently Available

Currently Available

Currently Available

To Be Procured

To Be Procured

To Be Procured

To Be Procured

To Be Procured

To Be Procured 


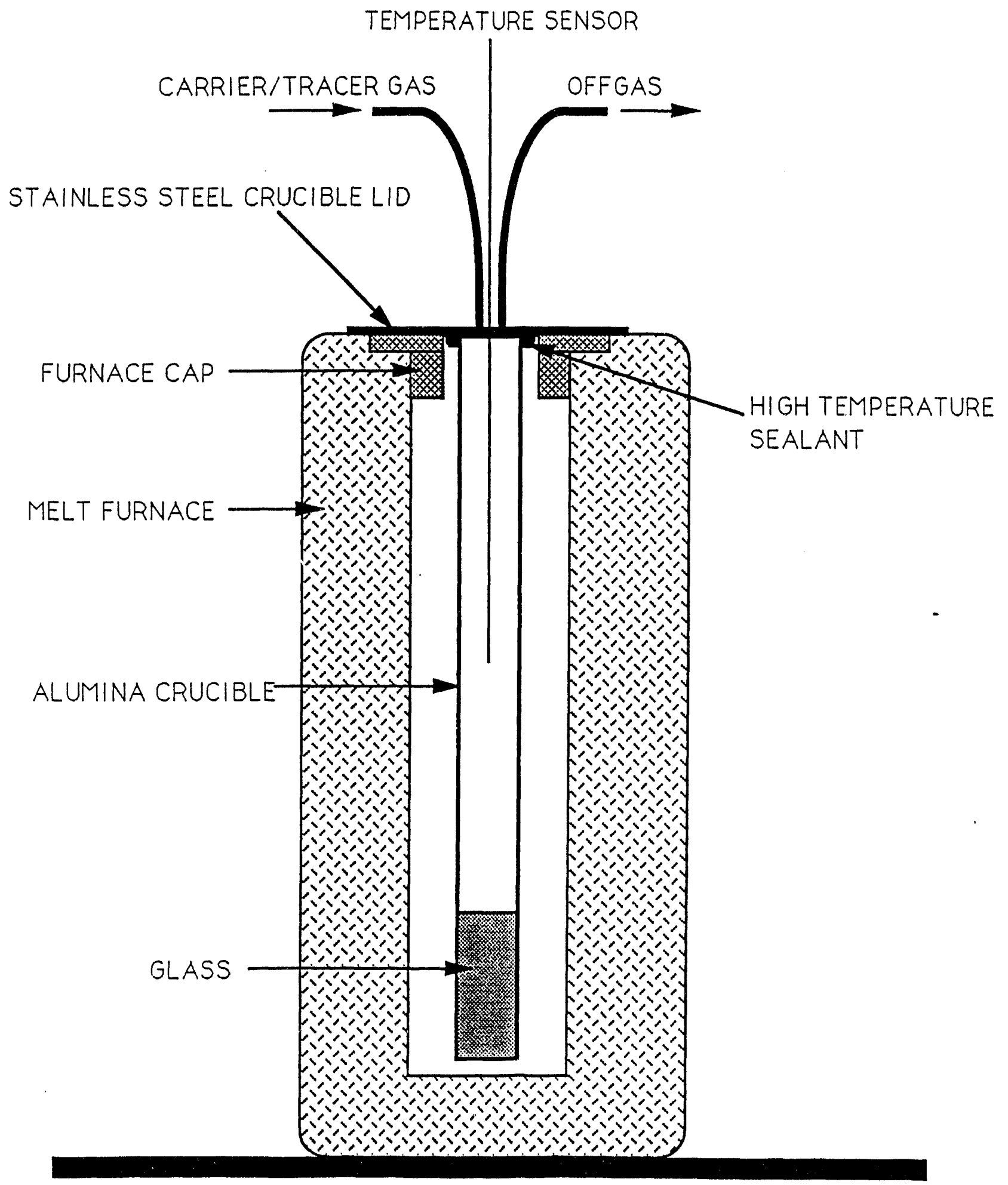

Figure 2. Melt Furnace and Crucible Setup 
The designation "Currently Available" means that the equipment is part of the existing formating offgas analysis system and can be used for the vitrification offgas analysis as well. Items "To Be Procured," specifically for vitrification offgas analysis, include a high-capacity mass-flow controller, custom alumina crucible, melt and annealing furnaces, calibration/carrier gases, wafering saw, and a Pora Plot $U$ column for the GC. A high-capacity mass-flow controller is needed to dilute offgases to sufficient levels for analysis. Alumina or other selected crucibles are not available in the desired geometry and will have to be special orciered. Furnaces capable of handling the custom crucibles and offgas apparatus are not typical and will need to be procured. Calibration and carrier gases will be restocked as necessary. A wafering saw is needed for trimming the crucible away from the glass.

\section{Compatibility of Melting Method with Product Testing}

Table 2 provides a comparison of procedural steps for the previous and proposed radioactive melting methods along with those for the Composition Variability Study (CVS) method. Previous radioactive feeds have been melted in Denver Fire Clay crucibles exposed to air and were poured into bar molds for quenching and annealing. The new method will include melting feed in alumina or other crucibles under inert or air atmosphere, air quenching, and annealing, all within the same crucible. Under the new method, the radioactive glass will be consistent with glass redox procedures used by $\mathrm{K}$. Wiemers (PNL) that entail sealing the crucible and lid to eliminate oxidation of the melt from atmospheric oxygen. During recent melter experiments, the melt furnace has been more oxidizing than crucible melts exposed to air; therefore, redox measurements will not be directly comparable to melter redoxes. However, the radioactive crucible redox will provide a direct comparison with simulant crucible redoxes. The glass should be compatible with durability testing (i.e., PCT and MCC-1) and crystallinity because steps have been included to ensure glass homogeneity and quenching. Although the new method is slightly different, it is expected to produce acceptable glass. Confirmation work will be performed with simulants prior to running core samples. 
Table 2. Comparison of Melt Methods

\begin{tabular}{||c|l|l|l||}
\hline $\begin{array}{c}\text { Crucible } \\
\text { Type: }\end{array}$ & $\begin{array}{l}\text { Composition Variability } \\
\text { Study }\end{array}$ & \multicolumn{1}{|c|}{$\begin{array}{c}\text { Previous Radioactive } \\
\text { Method }\end{array}$} & \multicolumn{1}{|c|}{$\begin{array}{c}\text { Proposed Radioactive } \\
\text { Method }\end{array}$} \\
\hline Step 1 & $\begin{array}{l}\text { Mix raw chemicals as a } \\
\text { batch in disk mill }\end{array}$ & $\begin{array}{l}\text { Calcine by ramping melt } \\
\text { furnace to } 600^{\circ} \mathrm{C} \text { at } \\
225^{\circ} \mathrm{C} / \mathrm{h} \text { hold at } 600^{\circ} \mathrm{C} \text { for } \\
2 \mathrm{~h} \text { let cool }\end{array}$ & $\begin{array}{l}\text { Seal lid to crucible \& } \\
\text { calcine by ramping melt } \\
\text { furnace to } 600^{\circ} \mathrm{C} \text { at } \\
225^{\circ} \mathrm{C} / \mathrm{h} \text { hold at } 600^{\circ} \mathrm{C} \text { for } \\
\text { lid) }\end{array}$ \\
\hline Step 2 let cool
\end{tabular}

\section{Location of Work}

There are two locations for this testing that appear to be appropriate: 1) the 325 A-hot cell facility where radioactive formating is being performed, and 2) the 324/D-cell where radioactive melting is currently being performed. Either facility could 
be used for the offgas analysis during the vitrification of the core samples; however, the

325 Building is the recommended location based on the following reasons:

1. A fume hood is currently being installed adjacent to $325 \mathrm{~A} / \mathrm{C}$-cell for future formating offgas analysis. Offgas equipment will be permanently installed in the fume hood. This same equipment will already be set up as a result of the formating offgas analyses before vitrification. Performing both formating and melting in the same location will minimize the possibility of damaging equipment during transport and reduce the cost and schedule per test by decreasing setup time.

2. Either a hood or a glovebox adjacent to the hot cell is required for locating and operating the offgas analyzers. In 324/D-cell, a large glovebox was fabricated several years ago and is waiting for someone to pay for installation. The only place available for a hood is on the end of this glovebox. The cost for installation of the hood and glove box is estimated at $\$ 100 \mathrm{~K}$. If a hood and glove box were installed, the hood location would necessitate a 30 -to 40 -ft offgas line to the analysis equipment resulting in added response time to the system. No savings will be recognized by using existing vitrification equipment in $324 / \mathrm{D}$-cell because new furnaces will be needed that are compatible with the elongated crucible shape and offgas penetrations.

\section{Simulant Testing}

The system will be cold tested using available simulants to ensure that it will operate properly in a hot-cell environment. The data will be compared with previous simulant data generated in the Glass Envelope Definition crucible melt system. Simulants prepared to match each core sample will be tested as a comparison to each core sample. These simulants will be the same as those prepared for formating offgas testing.

\section{Data Analysis and Reporting}

The data from simulant and radioactive testing will be analyzed and compared. Results will also be compared with the Glass Envelope Definition simulant data. Analysis of the data will be included in the final report of the radioactive sample.

\section{Cost and Schedule Estimates}

Itemized cost and schedule estima:es for these studies are provided in Table 3 . The total costs shown are those necessary to set up and perform offgas measurements on the 
Table 3. Itemized Estimated Costs and Schedule

\begin{tabular}{||l|c||}
\hline & Estimated Cost \\
\hline Equipment & $\$ 4.0 \mathrm{~K}$ \\
Custom Crucibles and Lids & $1.5 \mathrm{~K}$ \\
Melt Furnace & $1.5 \mathrm{~K}$ \\
Annealing Furnace & $3.0 \mathrm{~K}$ \\
Mass-flow Controller and Control Box & $1.5 \mathrm{~K}$ \\
Calibration/Carrier Gases & $5.0 \mathrm{~K}$ \\
Wafering Saw & $8.5 \mathrm{~K}$ \\
Miscellaneous/Adaptation & $\$ 25.0 \mathrm{~K}$ \\
& $30.0 \mathrm{~K}$ \\
\hline Installation Total & $15.0 \mathrm{~K}$ \\
\hline Test Planning and Procedure Modification & $25.0 \mathrm{~K}$ \\
\hline Data Analysis and Reporting & $10.0 \mathrm{~K}$ \\
\hline Simulant Testing (in-cell) & $10.0 \mathrm{~K}$ \\
\hline Radioactive Testing & $\$ 115.0 \mathrm{~K}$ \\
\hline Total Cost & 6 to $7 \mathrm{months}$ \\
\hline Schedule for Completion of First Core Sample & $\$ 60.0 \mathrm{~K}$ \\
\hline Cost for Testing Additional Core Samples & \\
\hline
\end{tabular}

first radioactive core sample. The schedule shown is for completing the first radioactive test but does not include reporting, which will be a part of the overall test report. Cost information for repeating the test on each additional radioactive core sample is also provided. 
$1 / 14 / 93$

Chuck

I DON KNOW WHAT K END OF DEAL YO $U$ HAVE WORKED OUT W/ EUGENIE ON TIES PROPOSAL BUT YOU MEG MT WANT TO TAKE A CLOSED LOOK AT IT.

I HAVE SEVERA COMPORTS:

1. EITHEX THF CARRIER GAS OK OFF GAS LEAT SWOULD EX TEND FURThER DOWN INTO RUE CRUCIBLE- SO THE GAS FLOWN IS WOT SHORT CIRCUITED. I BEZDENE THAT THIS IS HOW PETE SET UP TUT CKUCESCF FOR KARYN'S WORK.

2. SHOULD A COLO FINGEX BG PUT IN? CAN YOU U SF A COLD FEarer Far a nOT cell?

3. HOW DOES THIS METKSD COMPARE TO THL- STANOARO CRUCDPW (SCALED) TEST? IE. IS THIS METHOD ANY MURE DR LIS REPRESENTATIVE OF THE OXTAATEON STATE EN DUE MELTER THAN THE CRUCIBLE TEST METHOD? IF IT IS LESS ROAR SEATATID, THEN CAN WE AFFord TO LO SE THE DATA That wOULD BO

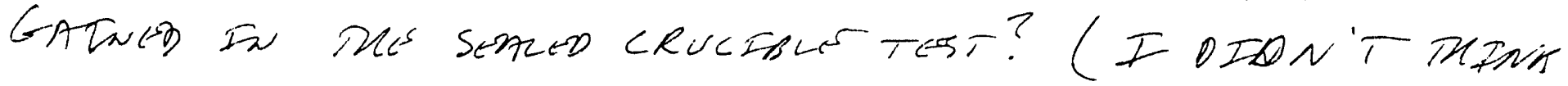
WE HAD ANY CORE SAMPLE LEFT DO R LA BRUNO WITH)

Res 


\section{a}

11
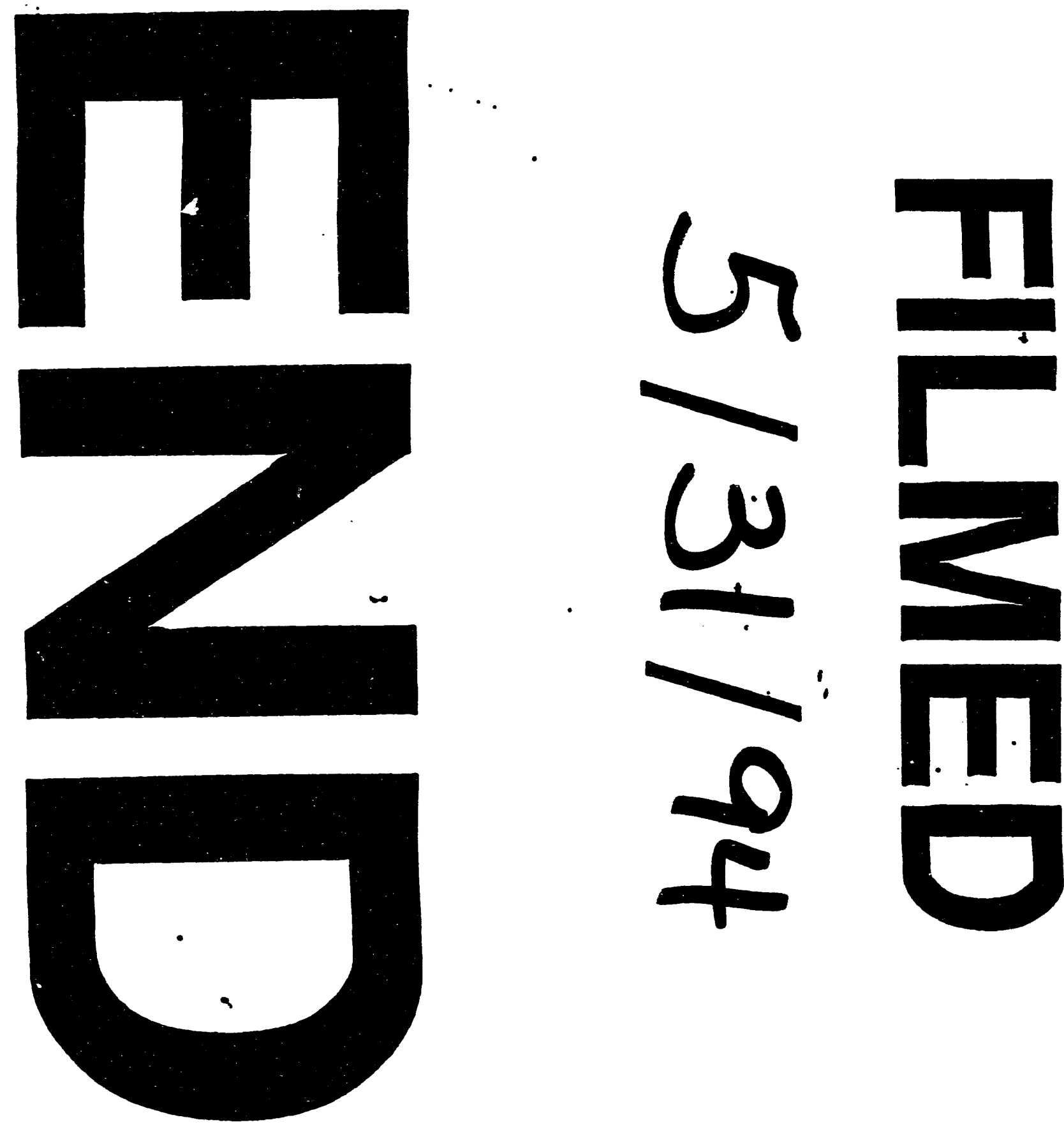

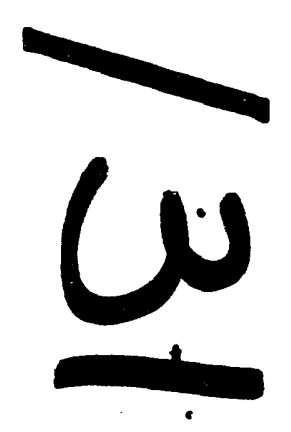

$\longrightarrow$ 0

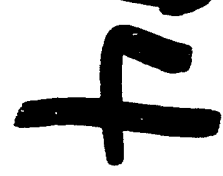
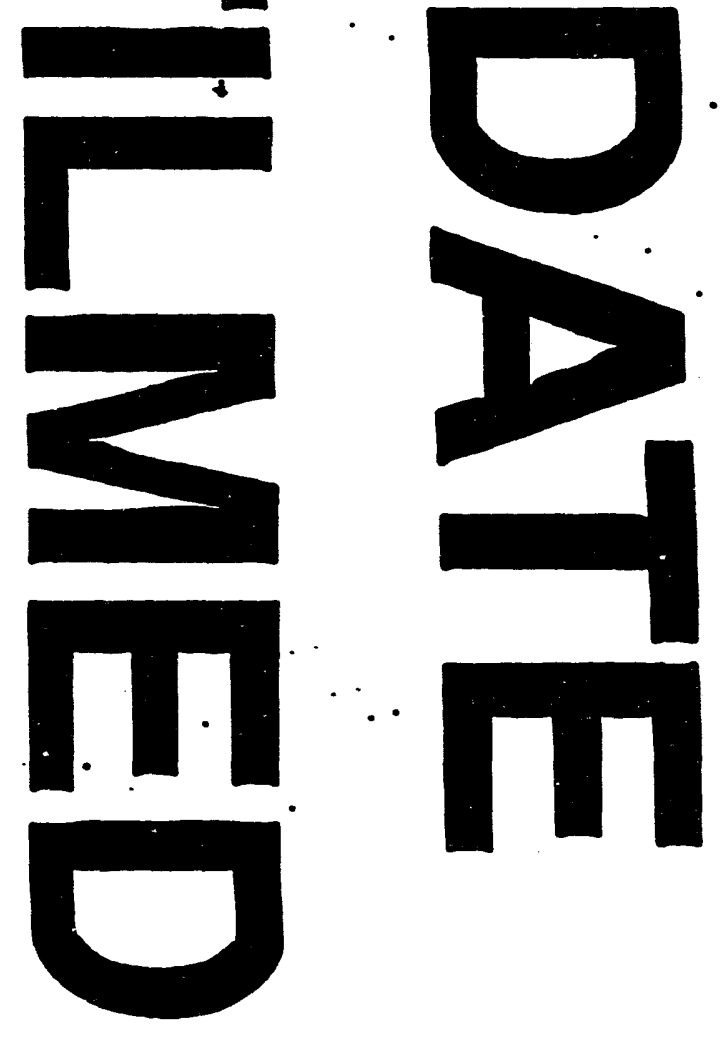
